SCIENTIFIC REPORT

\title{
Limbal epithelial crypts: a novel anatomical structure and a putative limbal stem cell niche
}

\author{
H S Dua, V A Shanmuganathan, A O Powell-Richards, P J Tighe, A Joseph
}

Br J Ophthalmol 2005;89:529-532. doi: 10.1136/bjo.2004.049742

Background/aims: There is substantial evidence that mammalian epithelial stem cells are located within well defined niches. Although the corneoscleral limbus is acknowledged as the site of corneal epithelial stem cells no anatomical niche for such cells has yet been described. The authors undertook to re-evaluate the microanatomy of the limbus in order to identify possible sites that may represent a stem cell niche. Methods: Systematic serial 5-7 $\mu \mathrm{m}$ sections of human corneoscleral segments obtained from cadaver donors, were examined. The sections were stained with haematoxylin and eosin or toludine blue. Sections with specific areas of interest were further examined immunohistologically for the corneal epithelial marker cytokeratin 14 and the "stem cell" marker ABCG2 transporter protein.

Results: Distinct anatomical extensions from the peripheral aspect of the limbal palisades were identified. These consist of a solid cord of cells extending peripherally or circumferentially. The cells stained positive for CK14 and ABCG2.

Conclusions: A novel anatomical structure has been identified at the human limbus, which demonstrates characteristics of being a stem cell niche. The authors have termed this structure the limbal epithelial crypt.

M ost self renewing tissues are served by stem cells. Stem cells are poorly differentiated, slow cycling cells with a great capacity for clonogenic expansion and error free division. They are self renewing, can proliferate indefinitely, and survive for the duration of the organ(ism) in which they reside. Stem cells usually are confined to their "niche," a specific location within the organ where the microenvironment supports and maintains the "stemness" of stem cells and affords a degree of protection. ${ }^{1}$ In solid organs, where cell migration commences at one point and progresses until the cells are shed at a distant point(s), the stem cell niche is usually located at the point of commencement. The key attributes of stem cells are their potency and plasticity-that is, their ability to give rise to multiple cell lineages and to transdifferentiate into totally different cell type(s) when relocated to a novel stem cell niche. ${ }^{2}$ At the ocular surface, there is a considerable body of evidence that supports the notion that the corneal epithelial stem cells are located in the palisades of Vogt at the corneoscleral limbus. ${ }^{3}{ }^{4}$ However, neither stem cells nor a specific niche for stem cells have been identified at the limbus, which is in part related to the lack of a specific stem cell marker. Most defined stem cell niches are located deeper in the tissue than their differentiated progeny. We therefore hypothesised that the human limbus must also contain an anatomically defined site that could serve as a niche.

\section{METHODS}

Corneoscleral rims from a total of five donors were analysed. Four of these were from fresh donors and the fifth from an organ cultured cornea. Donor ages were between 17 and 75 years. Segments of the rim were embedded in either optimum cutting temperature (OCT) compound (Dako Cytomation, Cambridgeshire, UK) and frozen in liquid nitrogen, fixed in formalin, and embedded in paraffin or fixed in glutaraldehyde and embedded in resin.

The tissue blocks were then cut into serial 5-7 $\mu \mathrm{m}$ sections. These were stained with haematoxylin and eosin and those fixed in glutaraldehyde were stained with toluidine blue. Every section was examined by light microscopy using a Nikon Labphot-2 microscope.

Immunohistochemistry was carried out using antibodies to CK14 (clone LL002, Serotec, Oxford, UK) and a recently described stem cell marker (side population cells) ABCG2 transporter (clone BXP-21, Oxford Biotechnology Ltd, Oxford, UK). A two step horseradish peroxidase method using diaminobenzidine (DAB) as substrate was employed.

Images of serial sections of an area of interest from one rim were later reconstructed to produce a three dimensional image using the Olympus analySIS pro software (Olympus Biosystems, Olympus Optical Co UK Ltd).

\section{RESULTS}

A novel and unique anatomical structure was identified at the limbus of all specimen studied. We termed the structure the limbal epithelial crypt (LEC) (figs l and 2). LECs extended from the peripheral aspect of the undersurface of an interpalisade rete ridge and extended either radially into the conjunctival stroma parallel to the palisade or circumferentially along the limbus at right angles to the palisade. The structure was widest at its origin from the rete ridge and gradually tapered to a narrow extension at its termination (figs 1 and 3). The length measured up to $120 \mu \mathrm{m}$. There were an estimated six per specimen of the human limbus.

On immunohistochemistry CK 14 staining was observed in all cells of the LEC and matched that of the more superficial cells (fig 3A). ABCG2 staining was maximum in the cells packed in the LEC and extended from the tail of the LEC towards the basal layer of the interpalisade rete ridge (fig 3B). The intensity of the basal cell staining for ABCG2 decreased more rapidly along the conjunctival basal layer than the limbal basal layer of cells. Some suprabasal cells showed membranous staining for this marker.

\section{DISCUSSION}

The limbus is an anatomical and functional unit located circumferentially along the periphery of the cornea at its junction with the sclera and the conjunctiva. A large body of circumstantial evidence, both clinical and basic, supports the view that corneal epithelial stem cells are located at the limbus. For instance, corneal epithelial regeneration and

Abbreviations: CK, cytokeratin; DAB, diaminobenzidine; LEC, limbal epithelial crypts; OCT, optimum cutting temperature; TAC, transient amplifying cells 


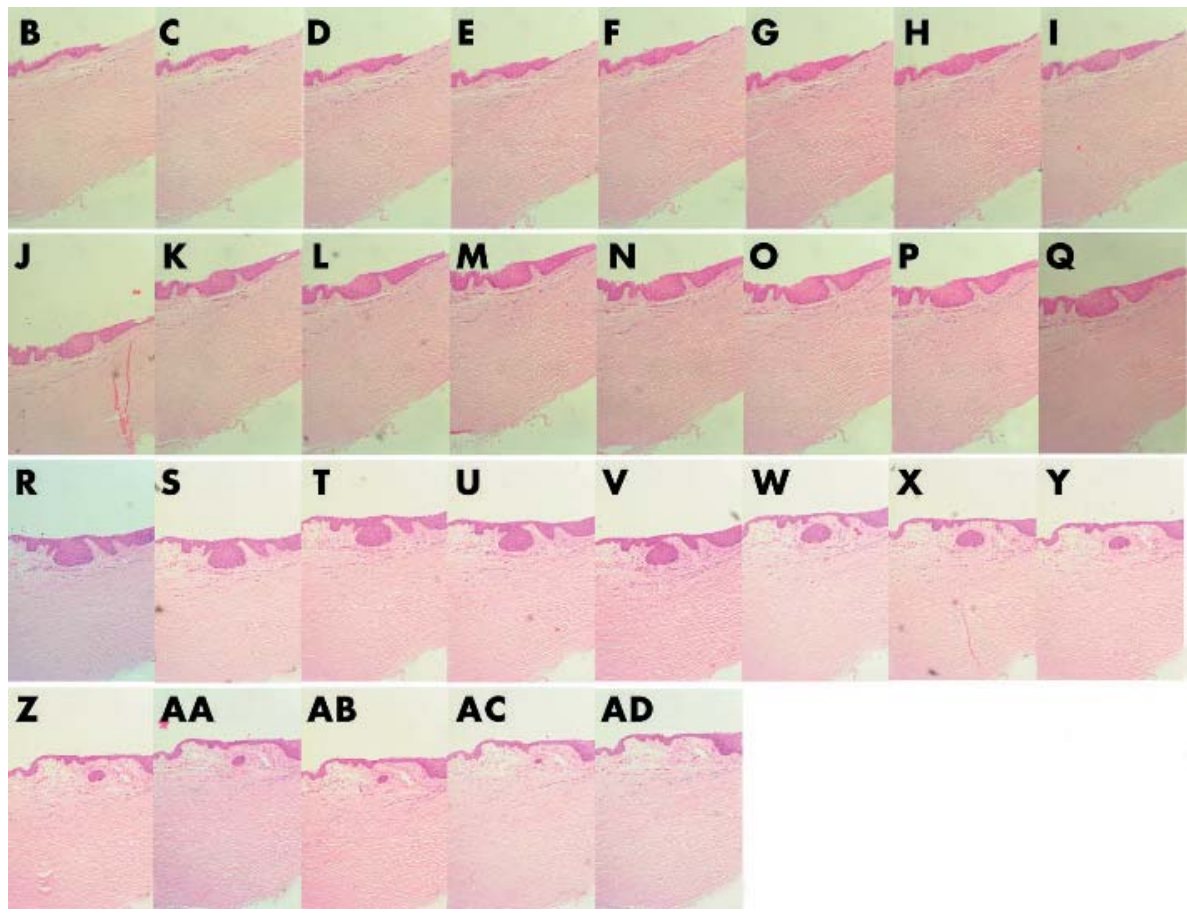

Figure 1 Serial sections stained with haematoxylin and eosin showing how the niche originates from the undersurface of a palisade at the limbus and gradually tapers towards its tail end in the substantia propria. This particular limbal epithelial crypt was oriented circumferentially along the limbus. Magnification $\times 100$.

wound healing occurs by a distinct centripetal migration of cells from the limbus. ${ }^{5}$ Limbal epithelial wounds heal by a characteristic circumferential migration of epithelial cells from any remaining intact epithelium. ${ }^{6}$ Limbal epithelial healing always precedes closure of central epithelial defects when both occur simultaneously. Disease or destruction of the corneoscleral limbus leads to ingress of conjunctiva derived cells, including goblet cells, and blood vessels onto the normally avascular corneal surface affecting its optical properties and leading to visual impairment or blindness. ${ }^{7}$ Surgical transplantation of autologous or homologous limbal tissue restores corneal epithelial structure and function. ${ }^{8}$ Despite this compelling clinical evidence, the identification of a specific marker for limbal stem cells or their niche remains elusive.

In 1971, the pericorneal palisades were first proposed to represent the source for renewal of corneal epithelial cells. ${ }^{9}$ Several laboratory studies too have indicated that corneal epithelial stem cells are located at the limbus. ${ }^{3}$ Limbal epithelial cells are cytokeratin (CK) 5/14+, CK19+, and CK3/ $12-.{ }^{10}$ These cells also show staining for vimentin, epidermal

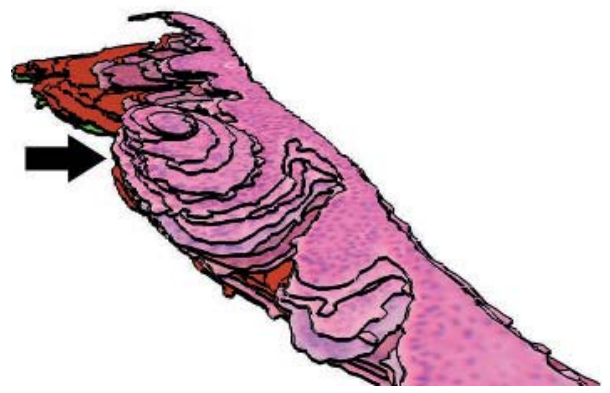

Figure 2 This is a three dimensional reconstruction, from serial histological sections, of the proposed stem cell niche for corneal epithelial stem cells. In this example the limbal epithelial crypt extends circumferentially along the corneal circumference (arrow).
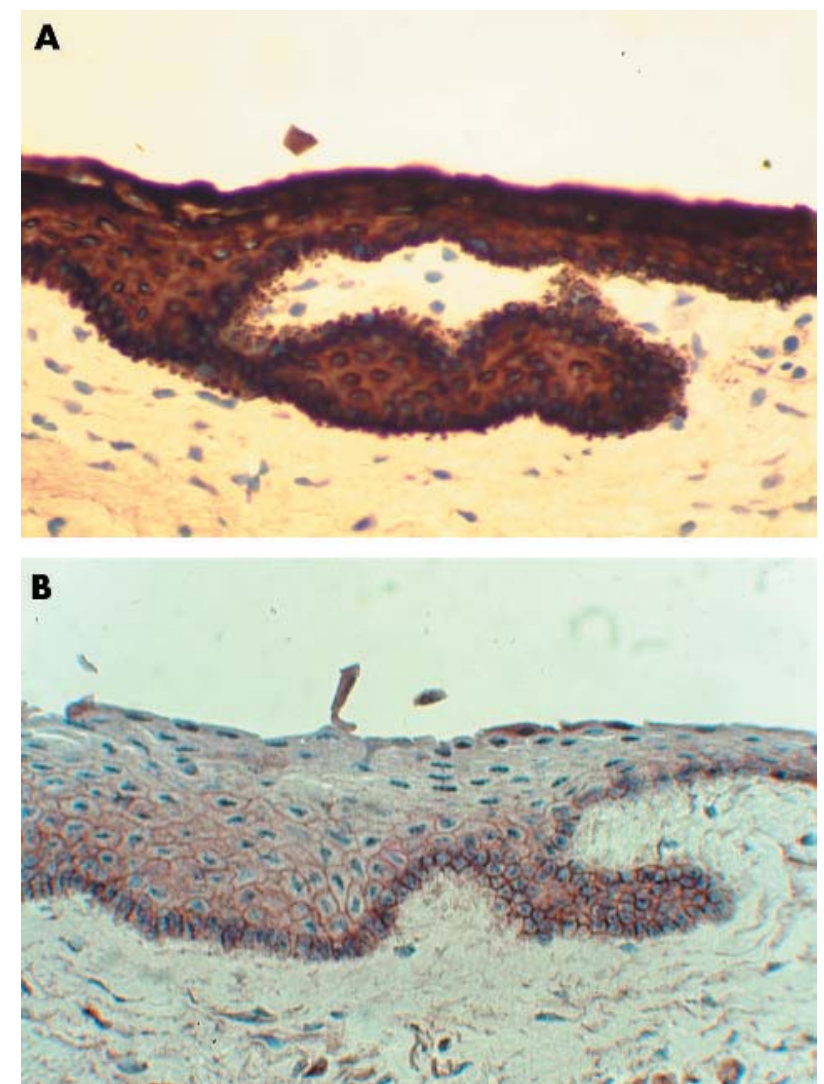

Figure 3 (A) Immunohistology of a LEC showing positive staining for cytokeratin 14 demonstrating that all cells in the crypt were epithelial in nature (immunoperoxidase, DAB $\times 400$ ). (B) Immunohistology of a LEC showing positive staining for $A B C G 2$. Note that all crypt cells stain while only basal cells of the epithelium stain with equal intensity to the crypt cells. Some suprabasal cells show membranous staining (immunoperoxidase, DAB $\times 400$ ). 
growth factor receptors, alpha enolase and are connexin 43 negative. ${ }^{11-14}$ Recently a nuclear transcription factor, p63 was proposed as a marker for limbal stem cells ${ }^{15}$ but this was not substantiated by other studies. ${ }^{7}$ Attempts to identify limbal stem cells and their niche by using antibodies to established haematopoietic stem cell markers such as CD34 and CD133 were also unsuccessful. ${ }^{16}$ In a recent fairly extensive immunohistological study of cultured human corneal epithelial cells using various cytokeratin and other markers (P63, integrin beta-1, and epidermal growth factor receptor) Kim et $a l^{17}$ did not demonstrate any single or combination of markers to identify stem cells. They did notice slow cycling cells which retained BrdU label indicating that some of the cells possessed this particular stem cell characteristic.

An ATP binding cassette transporter protein, ABCG2, is believed to be a marker of a side population cells that have the ability to efflux Hoechst 3342 dye. ${ }^{18}$ In a number of different organ systems, side population cells as determined by ABCG2 staining, are believed to contain, but not exclusively represent, stem cells. ${ }^{19-23}$ Recently Chen et a ${ }^{24}$ demonstrated that ABCG2 is primarily expressed in limbal basal cells and as such may constitute part of a stem cell phenotype. Similarly Watanabe et $a^{25}$ have also shown that a portion of limbal epithelial basal cells expressed ABCG2 and could represent the putative corneal epithelial stem cells.

Stem cells are known to be located in identifiable niches, which in self renewing tissues, are generally anatomically defined sites. ${ }^{26}$ The bulge region of the hair follicle and the crypt of an intestinal villus are two such examples. ${ }^{27}$ The microenvironment, in the midst of which the stem cells are located, contributes to the development and maintenance of the various unique features that characterise a stem cell. This microenvironment is made up of extracellular matrix components, other resident cells, and the products and signals they release. Collectively they constitute the niche. The immediate progeny of stem cells that step outside the niche have the potential to proliferate rapidly and provide the capacity for rapid expansion of the cell numbers in case of need. These cells are referred to transient amplifying cells (TAC). Several of the markers mentioned above differentiate limbal basal cells from peripheral corneal basal cells. This led to the notion that the entire limbal basal cell population may serve as stem cells. The identification of LEC in this study presents the limbal niche concept in a new light. If the LEC were to act as a repository of stem cells then the basal cells of the limbus and peripheral cornea would serve the function of TAC. This would also explain why several of the characteristics of the basal cells of the limbus are similar to those of the peripheral cornea and why attempts to identify differences between these two sets of basal cells, with a view to mark limbal stem cells have not proved fruitful.

The LEC are anatomically well defined structures and are located deeper in the substantia propria of the limbus providing both protection and a microenvironment of extracellular matrix with its multitude of resident cells. All cells within the LEC are epithelial in nature as demonstrated by their CK14 staining. ABCG2 staining was densest within the LEC cell population and extended along the basal cells of the limbus more than along the basal cells of the adjacent conjunctiva. If the cells within the LEC were at the bottom of the stem cell escalator and the basal epithelial cells at the top then such a distribution would be natural and expected. Although this in itself is not conclusive proof that the LEC cells are stem cells it does indicate that the LEC have the hallmarks of a "niche." As ABCG2 is not a specific stain for stem cells in the limbus or in any other organ, it is unlikely that all ABCG2 staining cells represent stem cells. In the light of the existing evidence from other organs it would appear that stem cells are contained within this particular population of cells, which could represent stem cells and their immediate progeny. This would also explain positive staining along the limbal basal epithelium and the larger proportion of cells staining positive for ABCG2 than could be accounted for by stem cells alone. Further studies on cell cycling within LEC and the proliferative potential of LEC cells will help in determining their stem cell nature.

\section{ACKNOWLEDGEMENTS}

This work was funded in part by the Charles Hayward Foundation and The Henry Smith Charity, and the Royal Blind Asylum and School/Scottish National Institution for the War Blinded, The Royal College of Surgeons of Edinburgh.

\section{Authors' affiliations}

H S Dua, V A Shanmuganathan, A O Powell-Richards, P J Tighe,

A Joseph, The Larry A Donoso Laboratory for Eye Research, Division of Ophthalmology and Visual Sciences, University of Nottingham, Nottingham, UK

This work was presented in part at 8th Nottingham Eye Symposium, January 2004 and at the Oxford Ophthalmic Congress July 2004.

Correspondence to: Professor Harminder S Dua, Division of Ophthalmology and Visual Sciences, B Floor, Eye Ear Nose and Throat Centre, University Hospital, Nottingham NG7 2UH, UK; harminder. dua@nottingham.ac.uk

Accepted for publication 2 August 2004

\section{REFERENCES}

1 Fuchs E, Segre J. Stem cells: a new lease of life. Cell 2000;100:143-55.

2 Poulsom R, Alison MR, Forbes SJ, et al. Adult stem cell plasticity. J Pathol 2002; 197:441-56.

3 Dua HS, Azuara-Blanco A. Limbal stem cells of the corneal epithelium. Surv Ophthalmol 2000;44:415-425.

4 Townsend WM. The limbal palisades of Vogt. Trans Am Ophthalmol Soc 1991;89:721-56.

5 Dua HS, Forrester JV. Clinical patterns of corneal epithelial wound healing. Am J Ophthalmol 1987; 104:481-9.

6 Dua HS, Forrester JV. The corneoscleral limbus in human corneal epithelial wound healing. Am J Ophthalmol 1990;1 10:646-56.

7 Dua HS, Joseph A, Shanmuganathan VA, et al. Stem cell differentiation and the effects of deficiency. Eye 2003;8:877-85.

8 Espana EM, Di Pascuale M, Grueterich $M$, et al. Keratolimbal allograft in corneal reconstruction. Eye 2004;18:406-17.

9 Davenger $M$, Evensen A. Role of the pericorneal papillary structure in the renewal of corneal epithelium. Nature 1971;229:560-1.

10 Schermer A, Galvin S, Sun TT. Differentiation-related expression of a major $64 \mathrm{~K}$ corneal keratin in vivo and in culture suggests limbal location of corneal epithelial stem cells. J Cell Biol 1986;103:49-62.

11 Zieske JD, Wasson M. Regional variation in distribution of EGF receptor in developing and adult corneal epithelium. J Cell Sci 1993;106:145-52.

12 Chung EH, DeGregorio PG, Wasson M, et al. Epithelial regeneration after limbus-to-limbus debridement. Expression of alpha-enolase in stem and transient amplifying cells. Invest Ophthalmol Vis Sci 1995;36:1336-43.

13 Zieske JD. Perpetuation of stem cells in the eye. Eye 1994;8:163-9.

14 Matic M, Petrov IN, Chen S, et al. Stem cells of the corneal epithelium lack connexins and metabolite transfer capacity. Differentiation 1997;61:251-60.

15 Pellegrini G, Dellambra E, Golisano O, et al. p63 identifies keratinocyte stem cells. Proc Natl Acad Sci U S A 2001;98:3156-61.

16 Joseph A, Hossain P, Jham S, et al. Expression of CD34 and L-selectin on human corneal keratocytes. Invest Ophthalmol Vis Sci 2003;44:4689-92.

17 Kim H-S, Song XJ, de Paiva CS, et al. Phenotypic characterization of human corneal epithelial cells expanded ex vivo from limbal explant and single cell cultures. Exp Eye Res 2004;79:41-9.

18 Zhou S, Scheutz JD, Bunting KD, et al. The ABC transporter Bcrpl/ABCG2 is expressed in a wide variety of stem cells and is a molecular determinant of the side-population phenotype. Nat Med 2001;7:1028-34

19 Goodell MA, Brose K, Paradis G, et al. Isolation and functional properties of murine hematopoietic stem cells that are replicating in vivo. J Exp Med 1996; 183:1797-806.

20 Lechner A, Leech CA, Abraham EJ, et al. Nestin-positive progenitor cells derived from adult human pancreatic islets of Langerhans contain side population (SP) cells defined by expression of the ABCG2 (BCRP1) ATPbinding cassette transporter. Biochem Biophys Res Commun 2002;293:670-4 
21 Kim $\mathrm{M}$, Turnquist $\mathrm{H}$, Jackson J. The multidrug resistance transporter $\mathrm{ABCG}$ (breast cancer resistance protein 1) effluxes Hoechst 33342 and is overexpressed in hematopoietic stem cells. Clin Cancer Res 2002;8:22-8.

22 Scharenberg CW, Harkey MA, Torok-Storb B. The ABCG2 transporter is an efficient Hoechst 33342 efflux pump and is preferentially expressed by immature human hematopoietic progenitors. Blood 2002;99:507-12.

23 Shimano K, Satake M, Okaya A. Hepatic oval cells have the side population phenotype defined by expression of ATP-binding cassette transporter ABCG2/BCRP1. Am J Pathol 2003;163:3-9.
24 Chen Z De Pavia CS Luo $L$ et al. Characterization of putative stem cell phenotype in human limbal epithelia. Stem Cells 2004;22:355-66.

25 Watanabe K, Nishida K, Yamato M, et al. Human limbal epithelium contains side population cells expressing the ATP-binding cassette transporter ABCG2. FEBS Lett 2004;565:6-10.

26 Fuchs E, Tumbar T, Guasch G. Socializing with the neighbours: stem cells and their niche. Cell 2004;116:769-78.

27 Tumbar T, Guasch G, Greco V, et al. Defining the epithelial stem cell niche in skin. Science 2004;303:359-63.

\section{Video reports}

To view the video reports in full visit our website www. bjophthalmol.com and click on the link to the video reports.

- Removal of INTACS: Stepped surgical complexity demonstrated with three cases. L Ilari, J C McAlister, D S Gartry

- The Nuclear Slide: A novel approach for unleashing the potential of the hydrodissection wave. A Naseri

- Giant pleomorphic adenoma of the lacrimal gland: pre- and post-operative function. A Jain, VI Nehru, U N Saikia, C E E Reddy

- Limbal-sparing lamellar keratoplasty. S L Watson, S Rauz, J Dart

- Bilateral Abducens Neuromyotonia. L H Ospina, N Aui-aree, D P Anderson

- Light to dark physiological variation in irido-trabecular angle width. GM Gazzard, P J Foster, D S Friedman, P T Khaw, S K L Seah

Video Suite: Triamcinolone-assisted vitrectomy

- Triamcinolone-assisted removal of the posterior hyaloid to repair retinal detachment due to macular hole in high myopia. A Ueno, H Enaida, Y Hata, T Nakamura, T Hisatomi, K Fujisawa, T Kubota, T Sakamoto, T Ishibashi

- Triamcinolone acetonide-assisted Epiretinal Membrane Peeling. S D M Chen, C K Patel

- A suture technique to manage a case of severe early flap displacement after laser in situ keratomileusis. L Spadea, P Pantaleoni, G Bianco

- Reconstruction of the Ocular Surface in LOGIC Syndrome. E Moore, V Kumar, J R Ainsworth, S Shah

- Laser Photocoagulation for Posterior Segment Intraocular Parasites. T Prabriputaloong, S Asawaphureekorn

- Feeder Vessel Treatment with High Speed ICG Angiography. D Stanescu-Segall, G Coscas, F Coscas, G Soubrane

- Endoscopy to aid anterior segment surgery. J E Moore, A Sharm

- Penetrating ocular injury due to a fish hook: Surgical removal. SD M Chen, D Chiu, C K Patel

- Retinal Ganglion Cell Axon Response to Guidance Molecules. S F Oster and D W Sretavan

- Marin-Amat Syndrome. A Jogiya, C Sandy

- Excision of subcutaneous Dirofilariasis of the eyelid. D Mallick, T P Ittyerah

- Thixotropy: a novel explanation for the cause of lagophthalmos after peripheral facial nerve palsy. M Aramideh, J H T M Koelman, P P Devriese, F VanderWerf, J D Speelman

- Surgical revision of leaking filtering blebs with an autologous conjunctival graft. K Taherian, A Azuara-Blanco

- Dipetalonema Reconditum in the human eye. T Huynh, J Thean, R Maini 